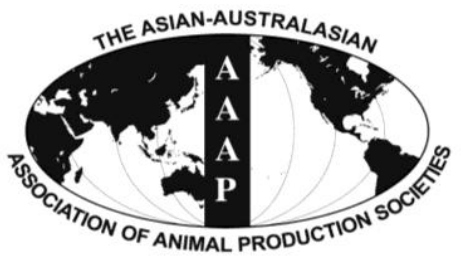

Asian Australas. J. Anim. Sci.

Vol. 26, No. 10 : 1424-1436 October 2013

http://dx.doi.org/10.5713/ajas.2013.13153

www.ajas.info

pISSN 1011-2367 eISSN 1976-5517

\title{
Using Plant Source as a Buffering Agent to Manipulating Rumen Fermentation in an In vitro Gas Production System
}

\author{
S. Kang and M. Wanapat* \\ Tropical Feed Resources Research and Development Center (TROFREC), Department of Animal Science, \\ Faculty of Agriculture, Khon Kaen University, Khon Kaen 40002, Thailand
}

\begin{abstract}
The objective of this study was to investigate the effect of banana flower powder (BAFLOP) supplementation on gas production kinetics and rumen fermentation efficiency in in vitro incubation with different ratios of roughage to concentrate in swamp buffalo and cattle rumen fluid. Two male, rumen fistulated dairy steers and swamp buffaloes were used as rumen fluid donors. The treatments were arranged according to a $2 \times 2 \times 3$ factorial arrangement in a Completely randomized design by using two ratios of roughage to concentrate (R:C; 75:25 and 25:75) and 3 levels of BAFLOP supplementation (0,2 and 4\% of dietary substrate) into two different kinds of rumen fluid (beef cattle and swamp buffalo). Under this investigation, the results revealed that the rumen ecology was affected by $\mathrm{R}: \mathrm{C}$ ratio. The $\mathrm{pH}$ declined as a result of using high concentrate ratio; however, supplementation of BAFLOP could buffer the $\mathrm{pH}$ which led to an improvement of ruminal efficiency. BAFLOP supplementation affected acetic acid (C2) when the proportion of concentrate was increased. However, there were no effect on total volatile fatty acid (TVFA) and butyric acid (C4) by BAFLOP supplementation. The microbial community was affected by BAFLOP supplementation, especially the bacterial population. As revealed by real-time PCR, the populations of $F$. succinogenes and $R$. albus were reduced by the high concentrate treatments while that of $R$. flavafaciens were increased. The populations of three dominant cellulolytic bacteria were enhanced by BAFLOP supplementation, especially on high concentrate diet. BAFLOP supplementation did not influence the ammonia nitrogen $\left(\mathrm{NH}_{3}-\mathrm{N}\right)$ concentration, while $\mathrm{R}: \mathrm{C}$ did. In addition, the in vitro digestibility was improved by either R:C or BAFLOP supplementation. The BAFLOP supplementation showed an effect on gas production kinetics, except for the gas production rate constant for the insoluble fraction (c), while treatments with high concentrate ratio resulted in the highest values. In addition, BAFLOP tended to increase gas production. Based on this study, it could be concluded that R:C had an effect on rumen ecology both in buffalo and cattle rumen fluid and hence, BAFLOP could be used as a rumen buffering agent for enhancing rumen ecology fed on high concentrate diet. It is recommended that level of BAFLOP supplementation should be at 2 to $4 \%$ of total dry matter of substrate. However, in vivo trials should be subsequently conducted to investigate the effect of BAFLOP in high concentrate diets on rumen ecology as well as ruminant production. (Key Words: Banana Flower Powder, Buffalo, Cattle, PCR Technique, Rumen Buffer, Rumen Fermentation)
\end{abstract}

\section{INTRODUCTION}

High carbohydrate feeds are important components of ruminant diets. Rations based on cereal grains, such as barley, promote rapid growth of sheep and cattle (McDonald et al., 1996). Reducing ruminal methane production can increase in ruminal propionate production, thereby lowering energy losses and contributing to higher overall efficiency of utilization of dietary energy for body weight gain (Mandebvu and Galbraith, 1999). However, diets high in cereals consequently reduce ruminal $\mathrm{pH}$ and

\footnotetext{
* Corresponding Author: M. Wanapat. Tel: +66-4320-2368, Fax: +66-4320-2368, E-mail: metha@kku.ac.th

Submitted Mar. 14, 2013; Accepted May 19, 2013; Revised Jun. 13, 2013
}

cellulolytic activity (Franzolin and Dehority, 1996), which induce acute or chronic acidosis, causing reduced feed intake and nutrient absorption as well as depressing animal performance (Owens et al., 1998). Rumen $\mathrm{pH}$ is one of the most critical determinants for rumen function as cellulolytic bacteria fail to grow below $\mathrm{pH}$ 6.0, while a slight increase in ruminal $\mathrm{pH}$ favours the activity of these bacteria (Santra et al., 2003).

Increasing ruminal input of buffers from the diet or saliva yields bases or buffers such as ammonia from degraded protein or non protein nitrogen (NPN) which helps prevent a depression in ruminal pH (Owens et al., 1998; Hussain and Miller, 1999). It was reported that dietary buffer would prevent depression in rumen $\mathrm{pH}$ and improve rumen ecology associated with high concentrate 
feeding (Santra et al., 2003). Mineral salts, such as sodium bicarbonate $\left(\mathrm{NaHCO}_{3}\right)$, have buffering capacity and are used to prevent acidic conditions in the rumen of animals fed on higher levels of concentrate. Ruminal total volatile fatty acid (VFA) concentration and $\mathrm{pH}$ are reported to increase with increasing levels of dietary mineral supplementation in Angora goats (Cetinkaya and Unal, 1992). Moreover, Koul et al. (1998) reported that supplementation of mineral salt in buffalo diets increased the number of ruminal total bacteria, as well as cellulolytic and amylolytic bacteria.

However, nutritionists have been trying to find and use the buffering capacity from feed resources which are rich in minerals due to the negative chemical residue remaining after using buffering chemicals. According to Ngamsaeng et al. (2006), banana flower has a potential use as a rumen buffer due to it containing a high level of mineral elements, especially $\mathrm{P}, \mathrm{Na}$ and $\mathrm{K}$. The hypothesis of the present research was that a feed resource rich in mineral elements such as banana flower powder (BAFLOP) could be used as a rumen buffering agent to enhance rumen ecology in animals fed on a high concentrate diet. Due to the lack and limitation of data on using banana flower as a buffering agent in the rumen and its effect on ruminant performance, the objective of this study was to investigate the efficiency of banana flower powder supplementation as rumen buffering agent using in vitro gas production techniques with different ratios of roughage to concentrate in swamp

Table 1. Feed ingredients and chemical composition of experimental diets

\begin{tabular}{lccc}
\hline Item & Concentrate & $\begin{array}{c}\text { Rice } \\
\text { straw }\end{array}$ & $\begin{array}{c}\text { Banana } \\
\text { flower } \\
\text { powder }\end{array}$ \\
\hline Ingredients (\% of dry matter) & & & \\
$\quad$ Cassava chip & 60.0 & & \\
Rice bran & 12.0 & & \\
Palm kernel meal & 10.0 & & \\
Coconut meal & 10.0 & & \\
Urea & 3.0 & & \\
Molasses & 2.0 & & \\
Mineral premix & 1.0 & & \\
Salt & 1.0 & & \\
Sulfur & 1.0 & & \\
Chemical compositions & & & \\
Dry matter (\%) & 87.1 & 93.4 & 94.0 \\
& ---------- \\
Organic matter & 87.6 & 87.4 & 84.0 \\
Crude protein & 16.1 & 2.3 & 12.8 \\
Neutral detergent fiber & 24.6 & 74.1 & 70.5 \\
Acid detergent fiber & 15.4 & 58.5 & 52.4 \\
Ash & 12.4 & 12.6 & 16.0 \\
Condensed tannins & $\mathrm{nd}^{\mathrm{a}}$ & $\mathrm{nd}^{\mathrm{a}}$ & 11.0 \\
\hline a Not determined & & & \\
\hline
\end{tabular}

buffalo and cattle rumen fluid.

\section{MATERIALS AND METHODS}

\section{Dietary substrate treatments, animals and experimental design}

Fresh banana flower was chopped, then sundried for about 3 or $4 \mathrm{~d}$ until air dry. Two ratios of roughage to concentrate (R:C) were used as dietary substrates. Substrates and dried banana flower were milled to pass through a 1-mm screen. Samples were prepared and weighed (total substrate mixture $200 \mathrm{mg}$ of dry matter; DM) into $60 \mathrm{~mL}$ bottles for various time incubations. Feed ingredients and chemical compositions of concentrate, rice straw and BAFLOP are shown in Table 1 and 2. Rice straw was used as a roughage source.

Two rumen fistulated of each dairy steers and swamp buffaloes were used as sources of rumen inoculum. The animals were fed on concentrate diet and rice straw was used as main roughage. The animals were placed on a routine for at least $21 \mathrm{~d}$ before sampling for rumen fluid where they were fed twice a day with water freely available and with access to a mineral block lick.

The experimental design was a $2 \times 2 \times 3$ factorial arrangement in a Completely randomized design (CRD), with three replications per treatment including triplicates of blank (medium only) in three incubation runs. The dietary treatments were two R:C ratios $(75: 25$ and $25: 75)$ and 3 levels of BAFLOP $(0,2$, and $4 \%$ of DM substrate) plus with two different kinds of rumen fluid (cattle and buffalo).

\section{Rumen and substrate inoculums}

Strict anaerobic techniques were used in all steps during the rumen fluid transferring and incubation periods. Rumen fluid samples were removed from each two of dairy steers and swamp buffaloes (1 liter per animal) before morning

Table 2. Mineral elements contained in banana flower powder

\begin{tabular}{lc}
\hline Item & Concentration \\
\hline Macro minerals $(\mathrm{g} / \mathrm{kg})$ & 21.8 \\
Nitrogen $(\mathrm{N})$ & 4.0 \\
Phosphorus $(\mathrm{P})$ & 54.2 \\
Potassium $(\mathrm{K})$ & 9.7 \\
Sodium $(\mathrm{Na})$ & 2.8 \\
Calcium $(\mathrm{Ca})$ & 3.4 \\
Magnesium $(\mathrm{Mg})$ & 3.1 \\
Sulfur $(\mathrm{S})$ & 1.3 \\
Chlorine $(\mathrm{Cl})$ & \\
Micro minerals $(\mathrm{ppm})$ & 290.0 \\
Iron $(\mathrm{Fe})$ & 200.0 \\
Manganese $(\mathrm{Mn})$ & 39.0 \\
Copper $(\mathrm{Cu})$ & 32.0 \\
Zinc $(\mathrm{Zn})$ &
\end{tabular}


feeding under vacuum via the rumen fistula into a 2 liter plastic flask and transferred into 2 pre-warmed thermos flasks (1 liter) (Menke et al., 1979; Makkar et al., 1995). The fluid was then transported to the laboratory.

The method used for in vitro fermentation was based on the technique described by Menke et al. (1979). Two hundred milligrams of feed samples (two R:C ratio) plus with BAFLOP supplementation were weighed into $60 \mathrm{~mL}$ bottle. The sets of sample incubations for the determination of fermentation end-products and gas production kinetics were prepared each time. The bottles with the mixture of substrate treatments were pre-warmed in a water bath at $39^{\circ} \mathrm{C}$ for $1 \mathrm{~h}$ before filling with $30 \mathrm{~mL}$ of rumen inoculums mixture. The bottles were then sealed with rubber stoppers and aluminium caps and incubated in a water bath set at $39^{\circ} \mathrm{C}$.

\section{Sample collection and analysis}

Gas production kinetics: During the incubation, the gas production kinetics were recorded at 1, 2, 4, 6, 8, 12, 24, 48, 72 , and $96 \mathrm{~h}$. Cumulative gas production data were fitted to the model of Orskov and McDonald (1979) as follows:

$$
y=a+b\left(1-e^{(-c t)}\right)
$$

Where $\mathrm{a}=$ the gas production from the immediately soluble fraction, $b=$ the gas production from the insoluble fraction, $\mathrm{c}=$ the gas production rate constant for the insoluble fraction $(b), t=$ incubation time, $(a+b)=$ the potential extent of gas production. $y=$ gas produced at time " $\mathrm{t}$ ".

Determination of fermentation parameters: The rumen inoculum mixtures were sampled at $0,6,12,24$, and $48 \mathrm{~h}$ of fermenting post inoculation. The $\mathrm{pH}$ values of each incubation time were immediately measured after each sampling time. Ruminal inoculum fluid was collected at 0 , 6,12 , and $24 \mathrm{~h}$ post inoculation. Rumen fluid samples were then filtered through four layers of cheesecloth. Samples were divided into three portions. The first portion, about twenty milliliters of mixed rumen inoculum, was put into plastic bottles for ammonia nitrogen $\left(\mathrm{NH}_{3}-\mathrm{N}\right)$ and VFA analysis. The sample was centrifuged at $16,000 \times \mathrm{g}$ for 15 min, and the supernatant was stored at $-20^{\circ} \mathrm{C}$ before $\mathrm{NH}_{3}-\mathrm{N}$ analysis by using the micro-Kjeldahl methods (AOAC, 1990) and VFA analysis by High performance liquid chromatography (HPLC; Instruments by controller water model 600E; water model $484 \mathrm{UV}$ detector; column novapak C18; column size $3.9 \mathrm{~mm} \times 300 \mathrm{~mm}$; mobile phase $10 \mathrm{mM} \mathrm{H}_{2} \mathrm{PO}_{4}$ [pH 2.5]) (Samuel et al., 1997). The second portion of $1 \mathrm{~mL}$ rumen fluid was collected and kept in a plastic bottle to which $9 \mathrm{~mL}$ of $10 \%$ formalin solution (1:9 $\mathrm{v} / \mathrm{v}$, rumen fluid: $10 \%$ formalin) were added and stored at $4^{\circ} \mathrm{C}$ for measuring microbial population. The total differential counts of bacteria, protozoa and fungal zoospores content of the rumen fluid were done according to the method of Galyean (1989) based on the use of a haemacytometer (Boeco, Hamburg, Germany). Rumen fluid was diluted using autoclaved distilled water $\left(121^{\circ} \mathrm{C}\right.$ for 15 min) as a medium, by 100, 10 and 10 times, and counted using $10 \times 40,10 \times 10$ and $10 \times 40$ ocular $\times$ objective of microscope for bacteria, protozoa and fungal zoospores respectively. The last portion was stored at $-20^{\circ} \mathrm{C}$ for DNA extraction (Yu and Morrison, 2004).

Extraction of genomic DNA and real-time PCR: Community DNA was extracted from $0.5 \mathrm{~g}$ of rumen content (fluid and digesta) by the $\mathrm{RBB}+\mathrm{C}$ method ( $\mathrm{Yu}$ and Morrison, 2004). In brief, the $\mathrm{RBB}+\mathrm{C}$ method employs two rounds of bead beating in the presence of $\mathrm{NaCl}$ and SDS, followed by sequential ammonium acetate and isopropanal precipitations. The precipitated nucleic acids were then treated with RNase A and proteinase $\mathrm{K}$, and the DNA was purified using columns from QIAGEN DNA Mini Kit (QIAGEN, Valencia, CA), according to manufacturer's recommendations.

The targeted microbial groups were total bacteria, the three predominant cellulolytic bacteria ( $F$. succinogenes, $R$. flavefaciens, and $R$. albus), total bacterial and protozoa. Primers for F. succinogenes, Fs219f (5'GGTATGGGATGAGCTTGC-3') and Fs654r (5'GCCTGCCCCTGAACTATC-3') were selected to allow amplification of all $10 \mathrm{~F}$. succinogenes strains deposited in GeneBank. For $R$. albus primers, Ra1281f (5'CCCTAAAAGCAGTCTTAGTTCG-3') and Ra1439r (5'CCTCCTTGCGGTTAGAACA-3') and for $R$. flavefaciens primers, Rf154f (5'-TCTGGAAACGGATGGTA-3') and Rf425r (5'-CCTTTAAGACAGGAGTTTACAA-3') were also selected to allow species-specific amplification of all seven $R$. flavefaciens strains deposited in GeneBank. These primers were chosen from previously published sequences that demonstrated species specific amplification (Koike and Kobayashi, 2001). Primers for total bacteria were F (5'-GCclamp-CCTACG GGAGGCAGCAG3'), R (5'GWATTACC GCGGCKGCTG3') according to Lane (1991) and protozoa were F (5'-GCTTTCGWTGGTAGTGTTT-3'), R (5'-ACT TGCCCTCYAATCGTWCT-3'), R (5'-GC-clamp-ACTT GCCCTCYAATCGTWCT-3') according to Sylvester et al. (2004). The conditions for the real-time PCR for $F$. succinogenes were as follows: $30 \mathrm{~s}$ at $94^{\circ} \mathrm{C}$ for denaturing, $30 \mathrm{~s}$ at $60^{\circ} \mathrm{C}$ for annealing and $30 \mathrm{~s}$ at $72^{\circ} \mathrm{C}$ for extension (48 cycles), except for 9 min denaturation in the first cycle and 10 min extension in the last cycle. Amplification of $16 \mathrm{~s}$ rDNA for $R$. albus and $R$. flavefaciens was carried out similarly except an annealing temperature of $55^{\circ} \mathrm{C}$.

The quantitative assay amplified target $16 \mathrm{~s}$ rDNA of each species by using specific primers and PCR conditions as described previously, the purified DNA was quantified by 
spectrophotometry with multiple dilutions. The target DNA was quantified using serial 10-fold dilutions from 101 to 108 DNA copies of the previously quantified DNA standards. Real-time PCR amplification and detection were performed in a Chromo 4TM system (Bio-Rad, USA). In brief, Biostools QuantiMix Easy SYG Kit was used for PCR amplification where samples were assayed in duplicate in a $20 \mu \mathrm{L}$ reaction mixture contained 4 to $6 \mathrm{mM} \mathrm{MgCl}_{2}, 10$ $\mu \mathrm{L}$ of Mastermix (including; Taq DNA polymerase, reaction buffer, dNTP mixture, $\mathrm{MgCl}_{2}$ and SybrGreen), $2 \mu \mathrm{L}$ of DNA template and $0.8 \mu \mathrm{L}$ of each primer $(10 \mu \mathrm{M} / \mu \mathrm{L})$.

Digestibility: At 24 and $48 \mathrm{~h}$ post inoculation a set of samples were tested for in vitro true digestibility (TD) according to Van Soest and Robertson (1985). In brief, the content of the bottle was transferred quantitatively to a spoutless beaker by repeated washing with $100 \mathrm{~mL}$ neutral detergent solution. The content was refluxed for $1 \mathrm{~h}$ and filtered through preweighed Gooch crucibles. The DM of the residue was weighed and in vitro TD of feed was calculated based on the following equation:

\section{$\mathrm{TD}=((\mathrm{DM}$ of feed taken for incubation-DF residue $)$ $\times 100) / \mathrm{DM}$ of feed taken for incubation.}

\section{Statistical analysis}

All obtained data were subjected to the General Linear Models (GLM) procedures of the Statistical Analysis System Institute (SAS, 1998) according to a $2 \times 2 \times 3$ factorial arrangement in a completely randomized design (CRD). The statistical model included species, R:C ratio, BAFLOP level, species $\times \mathrm{R}: \mathrm{C}$ ratio interactions, species $\times$ BAFLOP level interactions, $\mathrm{R}: \mathrm{C}$ ratio $\times \mathrm{BAFLOP}$ level interactions and species $\times \mathrm{R}: \mathrm{C}$ ratio $\times \mathrm{BAFLOP}$ level interaction. For all parameters, differences among treatments means were contrasted by Tukey's Multiple Comparison Test (Crichton, 1999).

\section{RESULTS}

\section{Feed ingredients and chemical compositions}

The feed ingredients and chemical compositions of concentrate, rice straw and BAFLOP used in this study are shown in Table 1 and 2. Concentrate was formulated to contain $16.1 \%$ crude protein (CP) and $24.6 \%$ neutral detergent fiber (NDF). Rice straw was used as the roughage source in this study and contained $2.3 \% \mathrm{CP}$ and $74.1 \% \mathrm{NDF}$. The banana flowers were choped, sun dried and ground into powder form for use in the experiment. BAFLOP contained high CP $(12.8 \%$ of DM) and condensed tannins $(11.0 \%$ of DM). Moreover, Table 2 shows the mineral elements contained in BAFLOP, especially with high values in potassium $(\mathrm{K})$ and sodium $(\mathrm{Na}) ; 54.2$ and $9.7 \mathrm{~g} / \mathrm{kg}$, respectively.

\section{Effect on gas production kinetics}

Cumulative gas production for each of the substrate treatments are presented as gas production and values for gas production kinetics models for substrates studied are given in Table 3 and Figure 1. The values for the estimated parameters obtained from the gas production kinetics models for supplements studied revealed that the intercept value (a) for the different treatments representing gas production from soluble fractions and gas production rate constants for the insoluble fraction (c) ranged from -6.09 to 2.84 and 0.03 to 0.07 , respectively. These values were significantly different between buffalo and cattle $(\mathrm{p}<0.001)$, whereas, gas production from the insoluble fraction (b), potential extent of gas production $(a+b)$ and cumulative gas production at $96 \mathrm{~h}$ were similar among treatments $(\mathrm{p}>0.05)$. The treatments with a high concentrate ratio in both cattle and buffalo showed a higher gas production. Moreover, there was a tendency effect of BAFLOP supplementation on accumulation gas production $(\mathrm{p}=0.08)$, however, the gas potential extent of gas production was higher than the non supplemented group $(\mathrm{p}<0.05)$. In Figure 1 , the cumulative of gas production sharply increased in the treatment with the high concentrate ratio, especially at $12 \mathrm{~h}$ of incubation time.

\section{Effect on true and NDF digestibility}

Effect of R:C with BAFLOP digestibility from in vitro incubation with swamp buffalo and dairy steers rumen fluid is shown in Table 4. There were no differences in in vitro true digestibility while NDF digestibility was higher in cattle than in buffalo $(p<0.05$. However, they were significantly affected by $\mathrm{R}: \mathrm{C}$ and the level of BAFLOP supplementation. When comparing among the supplemented group of BAFLOP, the results revealed higher values in the supplemented group rather than without especially in the group with higher ratio of concentrate. On the other hand, no differences were found between BAFLOP supplementation at 2 and $4 \%$ of the total substrate. In addition at $\mathrm{h} 48$ of incubation, there was an interaction effect between $\mathrm{R}: \mathrm{C}$ ratio and BAFLOP on NDF digestibility.

\section{Effect on ruminal $\mathrm{pH}$ and fermentation}

The $\mathrm{pH}, \mathrm{NH}_{3}-\mathrm{N}$, VFA profile and methane production $\left(\mathrm{CH}_{4}\right)$ values obtained from sampling times are given in Table 5, Figure 2 and 3. Under this experiment, the $\mathrm{pH}$ was linearly decreased with the extension time of incubation and was found significantly lower in the treatment with a higher level of concentrate ratio. Supplementation of BAFLOP at 2 and $4 \%$ of the total substrate could improve the $\mathrm{pH}$ as compared to unsupplemented group. Moreover, the concentration of $\mathrm{NH}_{3}-\mathrm{N}$ was increased dramatically based 
Table 3. Effect of roughage to concentrate ratio and banana flower powder supplementation on gas production kinetics and gas production from in vitro incubation of swamp buffalo and beef cattle rumen fluid

\begin{tabular}{|c|c|c|c|c|c|c|c|c|}
\hline \multirow{2}{*}{ Treatment } & \multirow{2}{*}{ Species } & \multirow{2}{*}{$\mathrm{R}: \mathrm{C}^{\mathrm{a}}$} & \multirow{2}{*}{ BAFLOP $^{b}$} & \multicolumn{4}{|c|}{ Gas production kinetics $^{c}$} & \multirow{2}{*}{$\operatorname{Gas}^{\mathrm{d}}$} \\
\hline & & & & $\mathrm{a}$ & $\mathrm{b}$ & $\mathrm{c}$ & $a+b$ & \\
\hline$\overline{\mathrm{T} 1}$ & \multirow[t]{6}{*}{ Buffalo } & \multirow[t]{3}{*}{$75: 25$} & 0 & 1.62 & 54.1 & 0.03 & 55.8 & 53.6 \\
\hline $\mathrm{T} 2$ & & & 2 & 2.84 & 58.5 & 0.03 & 61.3 & 57.5 \\
\hline $\mathrm{T} 3$ & & & 4 & 2.81 & 61.7 & 0.03 & 64.5 & 59.0 \\
\hline $\mathrm{T} 4$ & & \multirow[t]{3}{*}{$25: 75$} & 0 & -0.84 & 85.9 & 0.04 & 85.0 & 82.5 \\
\hline $\mathrm{T} 5$ & & & 2 & 0.00 & 84.7 & 0.04 & 84.7 & 81.8 \\
\hline T6 & & & 4 & -1.61 & 91.8 & 0.04 & 90.2 & 87.0 \\
\hline $\mathrm{T} 7$ & \multirow[t]{7}{*}{ Cattle } & \multirow[t]{3}{*}{$75: 25$} & 0 & 2.01 & 55.8 & 0.06 & 57.8 & 57.6 \\
\hline $\mathrm{T} 8$ & & & 2 & 1.78 & 58.2 & 0.04 & 60.0 & 59.2 \\
\hline T9 & & & 4 & 0.13 & 65.3 & 0.05 & 65.4 & 64.8 \\
\hline $\mathrm{T} 10$ & & \multirow[t]{4}{*}{$25: 75$} & 0 & -6.09 & 89.7 & 0.06 & 83.6 & 83.4 \\
\hline $\mathrm{T} 11$ & & & 2 & -3.59 & 88.3 & 0.07 & 84.7 & 84.7 \\
\hline $\mathrm{T} 12$ & & & 4 & -4.14 & 93.5 & 0.07 & 89.4 & 89.2 \\
\hline SEM & & & & 0.57 & 3.15 & 0.002 & 3.26 & 3.07 \\
\hline \multicolumn{9}{|l|}{ Interactions } \\
\hline Species & & & & $* * *$ & $\mathrm{~ns}$ & $* * *$ & ns & ns \\
\hline $\mathrm{R}: \mathrm{C}$ ratio & & & & $* * *$ & $* * *$ & $* * *$ & $* * *$ & $* * *$ \\
\hline BAFLOP & & & & $*$ & $*$ & $\mathrm{~ns}$ & $*$ & 0.08 \\
\hline Species $\times \mathrm{F}$ & & & & $* *$ & $\mathrm{~ns}$ & $*$ & ns & ns \\
\hline Species $\times \mathrm{E}$ & & & & $\mathrm{ns}$ & $\mathrm{ns}$ & $\mathrm{ns}$ & ns & ns \\
\hline $\mathrm{R}: \mathrm{C}$ ratio $>$ & & & & ns & $\mathrm{ns}$ & $*$ & ns & ns \\
\hline Species $\times$ F & $\times$ BAFLOP & & & $*$ & $\mathrm{~ns}$ & $*$ & ns & ns \\
\hline
\end{tabular}

${ }^{\mathrm{a}}$ Roughage:concentrate ratio. ${ }^{\mathrm{b}}$ Banana flower powder (\% of total substrate).

${ }^{\mathrm{c}} \mathrm{a}$, the gas production from the immediately soluble fraction; $\mathrm{b}$, the gas production from the insoluble fraction; $\mathrm{c}$, the gas production rate constant for the insoluble fraction (b); $a+b$, the gas potential extent of gas production.

${ }^{\mathrm{d}}$ Cumulative gas production at $96 \mathrm{~h}(\mathrm{~mL} / 0.2 \mathrm{~g}$ DM substrate).

$* \mathrm{p}<0.05 ; * * \mathrm{p}<0.01 ; * * * \mathrm{p}<0.001$.

on the time of incubation. $\mathrm{NH}_{3}-\mathrm{N}$ concentration found profile was affected by the $\mathrm{R}: \mathrm{C}$ and higher in the treatments lower in the treatments with high roughage ratio and higher with a higher level of concentrate. The acetate acid (C2) in cattle. There was no effect of BAFLOP supplementation and propionic acid (C3) were significantly affected by the on $\mathrm{NH}_{3}-\mathrm{N}$, while $\mathrm{R}: \mathrm{C}$ had an effect. In addition, the VFA BAFLOP supplementation, while butyric acid (C4) and

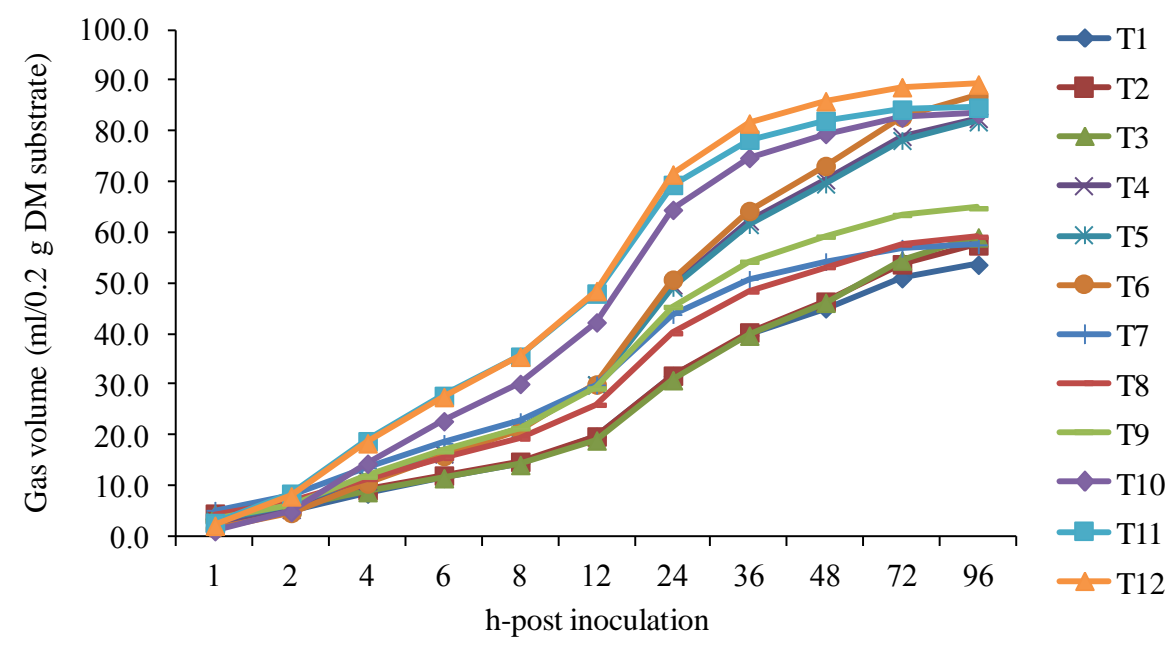

Figure 1. Effect of roughage to concentrate ratio with banana flower powder on cumulative gas production at different times of incubation in swamp buffalo and beef cattle rumen fluid. T1 = Buffalo+R:C 75:25+BAFLOP 0\%, T2 = Buffalo+R:C 75:25+BAFLOP 2\%, T3 = Buffalo+R:C 75:25+BAFLOP 4\%, T4 = Buffalo+R:C 25:75+BAFLOP 0\%, T5 = Buffalo+R:C 25:75+BAFLOP 2\%, T6 = Buffalo+R:C 25:75+BAFLOP 4\%, T7 = Cattle+R:C 75:25+BAFLOP 0\%, T8 = Cattle+R:C 75:25+BAFLOP 2\%, T9 = Cattle+R:C 75:25 +BAFLOP 4\%, T10 = Cattle+R:C 25:75+BAFLOP 0\%, T11 = Cattle+R:C 25:75+BAFLOP 2\%, T12 = Cattle+R:C 25:75+BAFLOP 4\%. 
Table 4. Effect of roughage to concentrate ratio and banana flower powder supplementation on digestibility from in vitro incubation of swamp buffalo and beef cattle rumen fluid

\begin{tabular}{|c|c|c|c|c|c|c|c|}
\hline \multirow{3}{*}{ Treatment } & \multirow{3}{*}{ Species } & \multirow{3}{*}{$\mathrm{R}: \mathrm{C}^{\mathrm{a}}$} & \multirow{3}{*}{ BAFLOP $^{\mathrm{b}}$} & \multicolumn{4}{|c|}{ In vitro digestibility (\%) } \\
\hline & & & & \multicolumn{2}{|c|}{ True } & \multicolumn{2}{|c|}{ NDF } \\
\hline & & & & $24 \mathrm{~h}$ & $48 \mathrm{~h}$ & $24 \mathrm{~h}$ & $48 \mathrm{~h}$ \\
\hline T1 & Buffalo & $75: 25$ & 0 & 57.1 & 75.1 & 35.7 & 62.7 \\
\hline $\mathrm{T} 2$ & & & 2 & 59.5 & 77.7 & 40.6 & 67.3 \\
\hline $\mathrm{T} 3$ & & & 4 & 62.0 & 81.1 & 45.6 & 72.9 \\
\hline $\mathrm{T} 4$ & & $25: 75$ & 0 & 74.4 & 80.6 & 37.8 & 52.8 \\
\hline T5 & & & 2 & 80.4 & 88.3 & 54.0 & 72.4 \\
\hline T6 & & & 4 & 81.6 & 89.5 & 58.4 & 76.2 \\
\hline $\mathrm{T} 7$ & Cattle & $75: 25$ & 0 & 59.6 & 77.2 & 39.5 & 65.9 \\
\hline $\mathrm{T} 8$ & & & 2 & 62.8 & 79.9 & 45.5 & 70.5 \\
\hline T9 & & & 4 & 63.2 & 81.9 & 47.2 & 74.1 \\
\hline $\mathrm{T} 10$ & & $25: 75$ & 0 & 78.9 & 81.3 & 48.7 & 54.5 \\
\hline $\mathrm{T} 11$ & & & 2 & 82.2 & 91.4 & 58.3 & 79.8 \\
\hline $\mathrm{T} 12$ & & & 4 & 86.9 & 91.1 & 70.3 & 79.7 \\
\hline SEM & & & & 5.07 & 1.60 & 3.08 & 2.22 \\
\hline \multicolumn{8}{|l|}{ Interactions } \\
\hline Species & & & & ns & ns & $*$ & 0.09 \\
\hline $\mathrm{R}: \mathrm{C}$ ratio & & & & $* * *$ & $* * *$ & $* * *$ & ns \\
\hline BAFLOP & & & & ns & $* *$ & $* *$ & $* * *$ \\
\hline Species $\times$ & & & & ns & ns & ns & ns \\
\hline Species $\times$ & & & & ns & ns & ns & ns \\
\hline $\mathrm{R}: \mathrm{C}$ ratio & & & & ns & ns & ns & $* *$ \\
\hline Species $\times$ & $\times$ BAFLOP & & & ns & ns & ns & ns \\
\hline
\end{tabular}

Table 5. Effect of roughage to concentrate ratio and banana flower powder supplementation on $\mathrm{pH}$, ammonia nitrogen, volatile fatty acid and methane production from in vitro incubation of swamp buffalo and beef cattle rumen fluid

\begin{tabular}{|c|c|c|c|c|c|c|c|c|c|c|c|}
\hline \multirow{2}{*}{ Treatment } & \multirow{2}{*}{ Species } & \multirow{2}{*}{$\mathrm{R}: \mathrm{C}^{\mathrm{a}}$} & \multirow{2}{*}{ BAFLOP $^{b}$} & \multirow{2}{*}{$\mathrm{pH}$} & \multirow{2}{*}{$\begin{array}{c}\mathrm{NH}_{3}-\mathrm{N} \\
(\mathrm{mg} / \mathrm{dL})\end{array}$} & \multirow{2}{*}{$\begin{array}{c}\text { TVFA } \\
(\mathrm{mmol} / \mathrm{L})\end{array}$} & $\mathrm{C} 2$ & $\mathrm{C} 3$ & $\mathrm{C} 4$ & \multirow{2}{*}{$\mathrm{C} 2: \mathrm{C} 3$} & \multirow{2}{*}{$\mathrm{CH}_{4}{ }^{\mathrm{c}}$} \\
\hline & & & & & & & \multicolumn{3}{|c|}{$\mathrm{mol} / 100 \mathrm{~mol}$} & & \\
\hline$\overline{\mathrm{T} 1}$ & Buffalo & $75: 25$ & 0 & 6.89 & 16.4 & 94.6 & 65.0 & 19.2 & 10.4 & 3.38 & 29.7 \\
\hline $\mathrm{T} 2$ & & & 2 & 6.95 & 16.7 & 93.2 & 64.0 & 19.7 & 9.5 & 3.26 & 29.2 \\
\hline $\mathrm{T} 3$ & & & 4 & 6.93 & 17.3 & 94.3 & 65.1 & 19.3 & 10.0 & 3.37 & 29.6 \\
\hline $\mathrm{T} 4$ & & $25: 75$ & 0 & 6.17 & 18.9 & 100.2 & 66.8 & 22.8 & 10.5 & 2.93 & 28.0 \\
\hline T5 & & & 2 & 6.52 & 20.2 & 102.8 & 69.7 & 22.1 & 11.1 & 3.15 & 28.9 \\
\hline T6 & & & 4 & 6.54 & 21.7 & 103.0 & 70.0 & 22.1 & 10.7 & 3.16 & 28.9 \\
\hline $\mathrm{T} 7$ & Cattle & $75: 25$ & 0 & 6.77 & 19.3 & 103.8 & 69.5 & 23.0 & 11.2 & 3.02 & 28.3 \\
\hline $\mathrm{T} 8$ & & & 2 & 6.84 & 20.0 & 102.4 & 70.8 & 21.4 & 10.2 & 3.31 & 29.3 \\
\hline T9 & & & 4 & 6.86 & 19.2 & 103.2 & 70.5 & 21.8 & 11.0 & 3.24 & 29.2 \\
\hline $\mathrm{T} 10$ & & $25: 75$ & 0 & 6.09 & 20.4 & 113.0 & 72.7 & 28.1 & 12.2 & 2.58 & 26.4 \\
\hline T11 & & & 2 & 6.46 & 22.6 & 113.5 & 76.2 & 24.9 & 12.5 & 3.06 & 28.6 \\
\hline $\mathrm{T} 12$ & & & 4 & 6.47 & 22.3 & 113.5 & 75.7 & 25.5 & 12.1 & 2.96 & 28.1 \\
\hline SEM & & & & 0.02 & 0.73 & 1.64 & 0.99 & 0.53 & 0.43 & 0.07 & 0.26 \\
\hline \multicolumn{12}{|l|}{ Interactions } \\
\hline Species & & & & $* * *$ & $* *$ & $* * *$ & $* * *$ & $* * *$ & $* *$ & $* *$ & $* *$ \\
\hline $\mathrm{R}: \mathrm{C}$ ratio & & & & $* * *$ & $* * *$ & $* * *$ & $* * *$ & $* * *$ & $* *$ & $* * *$ & $* * *$ \\
\hline BAFLOP & & & & $* * *$ & $\mathrm{~ns}$ & ns & $*$ & 0.06 & ns & $*$ & $* *$ \\
\hline Species $\times$ & ratio & & & $\mathrm{ns}$ & ns & ns & ns & ns & ns & ns & ns \\
\hline Species $\times$ & FOP & & & $\mathrm{ns}$ & ns & ns & ns & ns & ns & ns & 0.06 \\
\hline $\mathrm{R}: \mathrm{C}$ ratio & AFLOP & & & $* * *$ & ns & ns & ns & ns & ns & ns & 0.06 \\
\hline Species $\times$ & ratio $\times \mathrm{BA}$ & & & ns & ns & ns & ns & ns & ns & ns & ns \\
\hline
\end{tabular}

${ }^{a}$ Roughage:concentrate ratio. ${ }^{b}$ Banana flower powder (\% of total substrate).

${ }^{\mathrm{c}}$ Methane production (mM/L) calculated by Moss et al. $(2000)=0.45(\mathrm{C} 2)-0.275(\mathrm{C} 3)+0.4(\mathrm{C} 4)$.

$\mathrm{NH}_{3}-\mathrm{N}=$ Ammonia nitrogen; TVFA = Total volatile fatty acid; $\mathrm{C} 2$ = Acetic acid; C3 = Propionic acid; C4 = Butyric acid; C2:C3 = Acetic acid:propionic acid ratio.

$* \mathrm{p}<0.05 ; * * \mathrm{p}<0.01 ; * * * \mathrm{p}<0.001$ 


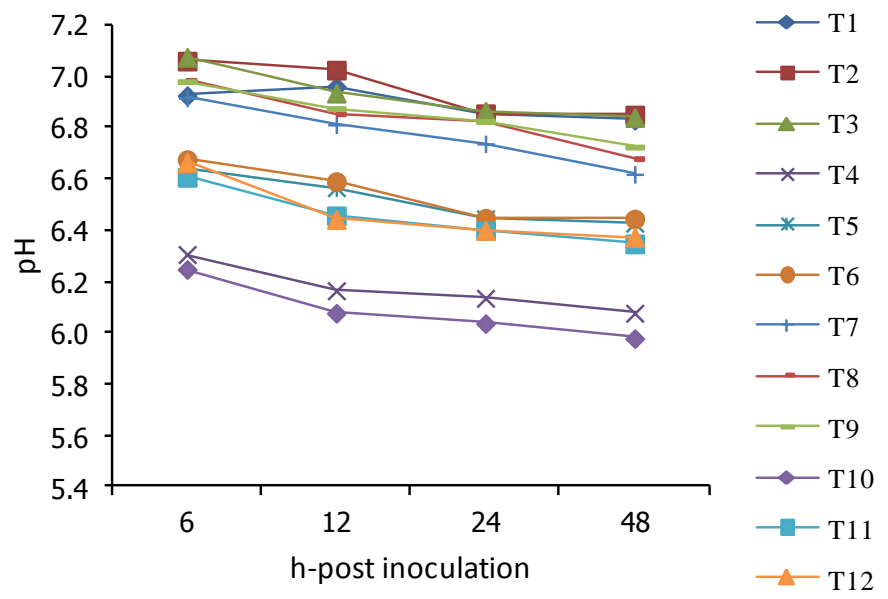

Figure 2. Effect of roughage to concentrate ratio with banana flower powder on ruminal $\mathrm{pH}$ at different times of incubation in swamp buffalo and beef cattle rumen fluid. T1 = Buffalo+R:C 75:25+BAFLOP 0\%, T2 = Buffalo+R:C 75:25+BAFLOP 2\%, T3 = Buffalo+R:C 75:25+BAFLOP 4\%, T4 = Buffalo+R:C 25:75+BAFLOP 0\%, T5 = Buffalo+R:C 25:75+BAFLOP 2\%, T6 = Buffalo+R:C 25:75+BAFLOP 4\%, T7 = Cattle+R:C 75:25+BAFLOP 0\%, T8 = Cattle+R:C 75:25+BAFLOP 2\%, T9 = Cattle+R:C 75:25+BAFLOP 4\%, T10 = Cattle+R:C 25:75+BAFLOP 0\%, T11 = Cattle+R:C 25:75+BAFLOP 2\%, T12 = Cattle+R:C 25:75+BAFLOP 4\%.

total volatile fatty acid (TVFA) were stable at all incubation times. The ratio $\mathrm{C} 2$ to $\mathrm{C} 3$ and methane $(\mathrm{CH} 4)$ were found lower in the group with higher level of concentrate ratio.

\section{Effect on rumen microbes}

Effect of R:C with BAFLOP on microbes from in vitro incubation with swamp buffalo and dairy steers fluid is shown in Table 6. The results revealed a significant effect on the bacterial population of different R:C and BAFLOP supplementation while protozoal and fungi zoospores showed a tendency effect by the BAFLOP supplementation. As compared with the unsupplemented group, supplementation was found higher in bacteria, fungi and protozoa populations $(\mathrm{p}<0.05)$. Without BAFLOP supplementation, the treatments with high concentrate ratio show a reduction of microorganisms' growth; however, it was enhanced in the group with supplementation. The groups of 2 and $4 \%$ of the total substrate BAFLOP supplementation showed no differences.

The real-time PCR for quantification of ruminal microbes (total bacterial, R. albus, F. succinogenes, $R$. flavefaciens and protozoa) is reported in Table 7 . The total bacteria and three dominant cellulolytic bacteria were found affected by species where cattle showed a higher value compared to bufflo. However, all were affected by $\mathrm{R}: \mathrm{C}$ ratio. While all microbes were found reduced by the high ratio of concentrate, $R$. flavefaciens was increased when using high concentrate. All groups of bacteria were enhanced by the

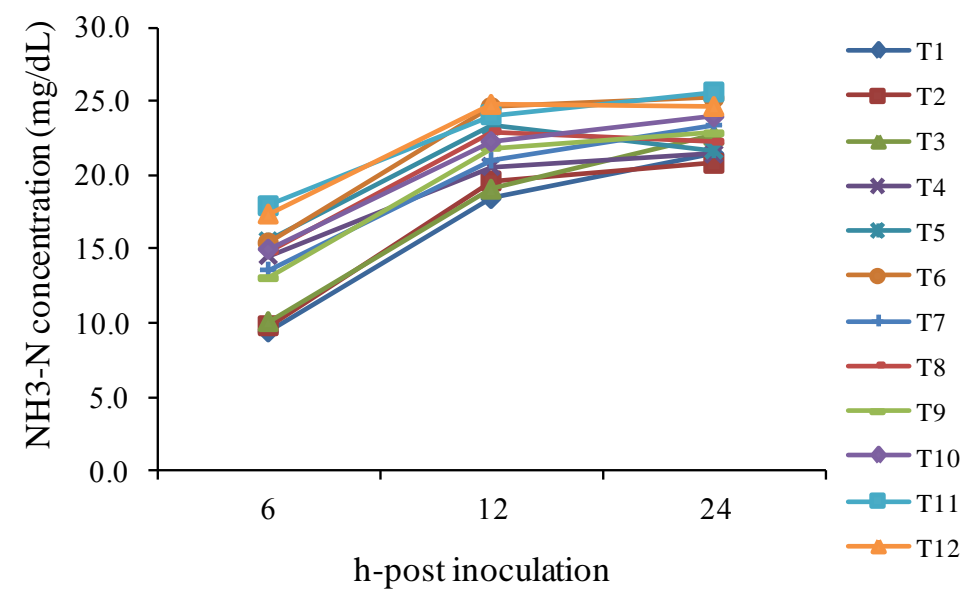

Figure 3. Effect of roughage to concentrate ratio with banana flower powder on ruminal $\mathrm{NH}_{3}-\mathrm{N}$ at different times of incubation in swamp buffalo and beef cattle rumen fluid. T1 = Buffalo+R:C 75:25+BAFLOP 0\%, T2 = Buffalo+R:C 75:25+BAFLOP 2\%, T3 = Buffalo+R:C 75:25+BAFLOP 4\%, T4 = Buffalo+R:C 25:75+BAFLOP 0\%, T5 = Buffalo+R:C 25:75+BAFLOP 2\%, T6 = Buffalo+R:C 25:75+BAFLOP 4\%, T7 = Cattle+R:C 75:25+BAFLOP 0\%, T8 = Cattle+R:C 75:25+BAFLOP 2\%, T9 = Cattle+R:C 75:25+BAFLOP 4\%, T10 = Cattle+R:C 25:75+BAFLOP 0\%, T11 = Cattle+R:C 25:75+BAFLOP 2\%, T12 = Cattle+R:C 25:75+BAFLOP 4\%. 
Table 6. Effect of roughage to concentrate ratio and banana flower powder supplementation on microorganism from in vitro incubation of swamp buffalo and beef cattle rumen fluid

\begin{tabular}{|c|c|c|c|c|c|c|c|c|c|c|c|c|}
\hline \multirow[t]{2}{*}{ Treatment } & \multirow[t]{2}{*}{ Species } & \multirow[t]{2}{*}{$\mathrm{R}: \mathrm{C}^{\mathrm{a}}$} & \multirow[t]{2}{*}{ BAFLOP $^{b}$} & \multicolumn{3}{|c|}{$\begin{array}{c}\text { Protozoa } \\
\left(\times 10^{5} \text { cell } / \mathrm{mL}\right)\end{array}$} & \multicolumn{3}{|c|}{$\begin{array}{c}\text { Fungi } \\
\left(\times 10^{6} \text { cell } / \mathrm{mL}\right)\end{array}$} & \multicolumn{3}{|c|}{$\begin{array}{c}\text { Bacteria } \\
\left(\times 10^{8} \text { cell } / \mathrm{mL}\right)\end{array}$} \\
\hline & & & & $6 \mathrm{~h}$ & $24 \mathrm{~h}$ & Mean & $6 \mathrm{~h}$ & $24 \mathrm{~h}$ & Mean & $6 \mathrm{~h}$ & $24 \mathrm{~h}$ & Mean \\
\hline$\overline{\mathrm{T} 1}$ & Buffalo & $75: 25$ & 0 & 2.8 & 3.5 & 3.5 & 4.0 & 4.8 & 4.7 & 16.8 & 38.8 & 26.7 \\
\hline $\mathrm{T} 2$ & & & 2 & 3.5 & 3.8 & 3.9 & 6.8 & 5.5 & 6.5 & 20.8 & 41.3 & 30.8 \\
\hline $\mathrm{T} 3$ & & & 4 & 4.5 & 4.0 & 4.5 & 6.3 & 5.3 & 6.2 & 25.8 & 46.0 & 33.3 \\
\hline $\mathrm{T} 4$ & & $25: 75$ & 0 & 1.5 & 2.5 & 2.3 & 3.5 & 2.5 & 3.5 & 13.3 & 26.0 & 19.1 \\
\hline T5 & & & 2 & 3.0 & 3.5 & 3.4 & 4.3 & 5.0 & 4.9 & 19.3 & 37.0 & 27.1 \\
\hline T6 & & & 4 & 2.5 & 3.8 & 3.2 & 5.3 & 4.3 & 5.3 & 21.3 & 36.3 & 28.4 \\
\hline $\mathrm{T} 7$ & Cattle & $75: 25$ & 0 & 4.0 & 2.8 & 4.3 & 5.0 & 3.0 & 4.6 & 22.8 & 31.8 & 33.6 \\
\hline T8 & & & 2 & 4.0 & 5.0 & 5.9 & 6.3 & 4.8 & 6.3 & 30.3 & 49.5 & 46.4 \\
\hline T9 & & & 4 & 5.3 & 4.5 & 5.7 & 8.3 & 5.0 & 7.5 & 38.8 & 47.3 & 46.1 \\
\hline $\mathrm{T} 10$ & & $25: 75$ & 0 & 2.3 & 3.8 & 3.8 & 3.8 & 3.3 & 3.6 & 18.3 & 22.5 & 25.2 \\
\hline $\mathrm{T} 11$ & & & 2 & 3.0 & 4.8 & 5.0 & 6.0 & 5.0 & 5.9 & 26.0 & 38.5 & 35.9 \\
\hline T12 & & & 4 & 4.3 & 5.8 & 5.7 & 5.5 & 4.8 & 5.6 & 33.8 & 37.3 & 37.2 \\
\hline SEM & & & & 0.74 & 0.61 & 0.54 & 1.07 & 0.55 & 0.56 & 2.39 & 2.56 & 1.48 \\
\hline \multicolumn{13}{|l|}{ Interactions } \\
\hline Species & & & & $\mathrm{ns}$ & 0.09 & ns & ns & ns & ns & $* * *$ & ns & $* * *$ \\
\hline $\mathrm{R}: \mathrm{C}$ ratic & & & & 0.06 & ns & ns & ns & ns & $*$ & 0.07 & $* * *$ & $* * *$ \\
\hline BAFLOI & & & & $\mathrm{ns}$ & 0.09 & 0.07 & $*$ & $*$ & $* *$ & $* *$ & $* * *$ & $* * *$ \\
\hline Species $x$ & $\mathrm{C}$ ratio & & & $\mathrm{ns}$ & ns & ns & ns & ns & ns & ns & ns & ns \\
\hline Species $x$ & AAFLOP & & & $\mathrm{ns}$ & ns & ns & ns & ns & ns & ns & ns & $\mathrm{ns}$ \\
\hline $\mathrm{R}: \mathrm{C}$ ratic & $\angle \mathrm{BAFLOP}$ & & & $\mathrm{ns}$ & ns & ns & ns & ns & ns & ns & ns & ns \\
\hline Species $\times$ & $\mathrm{C}$ ratio $\times \mathrm{E}$ & FLOP & & $\mathrm{ns}$ & ns & ns & ns & ns & ns & ns & ns & ns \\
\hline
\end{tabular}

${ }^{2}$ Roughage:concentrate ratio. ${ }^{\mathrm{b}}$ Banana flower powder (\% of total substrate). ${ }^{*} \mathrm{p}<0.05 ; * * \mathrm{p}<0.01 ; * * * \mathrm{p}<0.001$

Table 7. Effect of roughage to concentrate ratio and banana flower powder supplementation on cellulolytic bacteria and protozoa populations in in vitro incubation of swamp buffalo and beef cattle rumen fluid by using real-time PCR

\begin{tabular}{|c|c|c|c|c|c|c|c|c|}
\hline \multirow[b]{2}{*}{ Treatment } & \multirow[b]{2}{*}{ Species } & \multirow[b]{2}{*}{$\mathrm{R}: \mathrm{C}^{\mathrm{a}}$} & \multirow[b]{2}{*}{ BAFLOP $^{\mathrm{b}}$} & \multicolumn{5}{|c|}{ Real-time PCR technique, copies/mL of incubation } \\
\hline & & & & $\begin{array}{l}\text { Total bacteria } \\
\qquad\left(\times 10^{9}\right)\end{array}$ & $\begin{array}{l}\text { F. succinogenes } \\
\left(\times 10^{7}\right)\end{array}$ & $\begin{array}{l}\text { R. flavafaciens, } \\
\left(\times 10^{6}\right)\end{array}$ & R. albus $\left(\times 10^{6}\right)$ & Protozoa $\left(\times 10^{4}\right)$ \\
\hline $\mathrm{T} 1$ & Buffalo & $75: 25$ & 0 & 3.78 & 4.54 & 1.69 & 2.24 & 2.42 \\
\hline $\mathrm{T} 2$ & & & 2 & 3.16 & 3.65 & 1.65 & 2.88 & 2.33 \\
\hline $\mathrm{T} 3$ & & & 4 & 3.52 & 4.95 & 1.91 & 2.41 & 0.88 \\
\hline $\mathrm{T} 4$ & & $25: 75$ & 0 & 5.22 & 2.52 & 2.51 & 1.28 & 1.50 \\
\hline T5 & & & 2 & 5.90 & 4.29 & 2.74 & 2.28 & 2.23 \\
\hline T6 & & & 4 & 7.74 & 4.27 & 2.74 & 2.74 & 2.29 \\
\hline $\mathrm{T} 7$ & Cattle & $75: 25$ & 0 & 3.99 & 5.56 & 2.78 & 2.56 & 2.42 \\
\hline $\mathrm{T} 8$ & & & 2 & 4.29 & 5.47 & 2.84 & 2.63 & 2.33 \\
\hline T9 & & & 4 & 4.62 & 5.43 & 2.82 & 2.20 & 1.97 \\
\hline $\mathrm{T} 10$ & & $25: 75$ & 0 & 6.83 & 3.34 & 3.57 & 2.20 & 1.50 \\
\hline $\mathrm{T} 11$ & & & 2 & 7.65 & 5.25 & 4.00 & 3.42 & 2.23 \\
\hline $\mathrm{T} 12$ & & & 4 & 8.11 & 5.19 & 4.10 & 3.35 & 2.29 \\
\hline SEM & & & & 0.09 & 0.12 & 0.09 & 0.09 & 0.12 \\
\hline \multicolumn{9}{|l|}{ Interaction } \\
\hline Species & & & & $* * *$ & $* * *$ & $* * *$ & $* * *$ & 0.09 \\
\hline $\mathrm{R}: \mathrm{C}$ ratio & & & & $* * *$ & $* * *$ & $* * *$ & ns & ns \\
\hline BAFLOP & & & & $* * *$ & $* * *$ & 0.06 & $* * *$ & $*$ \\
\hline Species $\times \mathrm{F}$ & $\mathrm{C}$ ratio & & & $*$ & ns & ns & $* * *$ & 0.09 \\
\hline Species $\times \mathrm{E}$ & AFLOP & & & $* *$ & $*$ & ns & ns & 0.06 \\
\hline $\mathrm{R}: \mathrm{C}$ ratio $>$ & BAFLOP & & & $* * *$ & $* * *$ & ns & $* * *$ & $* * *$ \\
\hline Species $\times F$ & $\mathrm{C}$ ratio $\times \mathrm{B}$ & LOP & & $* * *$ & 0.06 & ns & ns & 0.06 \\
\hline
\end{tabular}

${ }^{\mathrm{a}}$ Roughage:concentrate ratio. ${ }^{\mathrm{b}}$ Banana flower powder $\left(\%\right.$ of total substrate). ${ }^{*} \mathrm{p}<0.05 ; * * \mathrm{p}<0.01 ; * * * \mathrm{p}<0.001$. 
BAFLOP supplementation, especially in the treatment with the high concentrate ratio $(\mathrm{p}<0.05)$.

\section{DISCUSSIONS}

\section{Feed ingredients and chemical composition}

The concentrate was mixed using available feed resources from the region which contained low structural carbohydrate and high CP. However, untreated rice straw was of lower quality in terms of $\mathrm{CP}$ and higher in fiber. On the other hand, banana flower powder was used as a supplement, contained $12.8 \% \mathrm{CP}$ which was similar to the value reported by Ngamsaeng et al. (2006). Moreover, BAFLOP enriches in condensed tannins. Reed et al. (1990) reported that higher levels of tannins may reduce cell wall digestibility by binding bacterial enzymes and/or forming indigestible complexes with cell wall carbohydrates. Condensed tannins can also facilitate forming of rumen bypass protein that might otherwise be lost through microbial deamination in the rumen (Barry et al., 1986; Tanner et al., 1994). This rumen by-pass protein is made possible by reactive components of $\mathrm{CT}$, which complex with soluble proteins, making them insoluble at rumen $\mathrm{pH}$ (5.8 to 6.8), but soluble and released at the more extreme $\mathrm{pH}$ conditions found in the abomasum ( $\mathrm{pH} 2.5$ to 3.5) and small intestine (pH 7.5 to 8.5) (Barry and Manley, 1984). In addition, as shown in Table 2, BAFLOP has a high content of mineral elements, especially potassium $(\mathrm{K})$ and sodium $(\mathrm{Na})$ and these values were found similar to the values presented by Ngamsaeng et al. (2006).

\section{Effect on gas production kinetics}

The present results revealed significant differences between buffalo and cattle on the intercept value (a) for the different treatments representing gas production from soluble fractions and gas production rate constants for the insoluble fraction (c), whereas gas production from the insoluble fraction (b), potential extent of gas production $(\mathrm{a}+\mathrm{b})$ and cumulative gas production at $96 \mathrm{~h}$ were similar among treatments. This study was similar to the finding of Chanthakhoun and Wanapat (2012) who reported that there was no difference between buffalo and cattle in gas production kinetics. This was also reported by Blummel and Orskov (1993), while Khazaal et al. (1993) reported the negative values for various substrates when using mathematical models to fit gas production kinetics. This was probably due to either a deviation from the exponential increase in fermentation or delays in the onset of fermentation due to microbial colonization. However, gas production kinetics and cumulative gas production at $96 \mathrm{~h}$ was significantly increased among treatments $(p<0.05)$ by the ratio of roughage to concentrate as BAFLOP supplementation showed a tendency effect. As reported by
Lunsin and Wanapat (2010) and Anantasook and Wanapat (2012), the gas production and gas production kinetics linearly increased with an increasing level of concentrate from 30 to $70 \%$. However, a high level of concentrate could lower the $\mathrm{pH}$ and affect the microbial population (Slyter, 1976). That was similar to the present finding which showed a higher gas production in the high R:C, meanwhile, BAFLOP supplementation could enhance the $\mathrm{pH}$ decrease in the treatment with high concentrate which resulted in higher gas production and kinetics in the supplemented group as compared to unsupplemented. However, there was no difference between the 2 and $4 \%$ of BAFLOP supplementation.

\section{Effect on true and NDF digestibility}

The in vitro true and NDF digestibility were significantly affected by $\mathrm{R}: \mathrm{C}$ and the level of BAFLOP supplementation and there was a difference between swamp buffalo and cattle. The in vitro true and NDF digestibility were found higher in the high level of concentrate ratio and it tended to show higher values in the buffalo group. This may be due to the high soluble carbohydrate contained in the treatments at the high level of concentrate ratio. According to Tripathi et al. (2004), total tract apparent digestibility showed linear increasing trends with increasing addition of sodium bicarbonate. In general, the digestibilities of DM and nutrients have been found to be improved with dietary addition of buffer due to the ability to maintain ruminal $\mathrm{pH}$ above the critical level (Mould et al., 1983). When comparing the supplemented groups with BAFLOP, the present results revealed higher values in the supplemented groups rather than those without especially in the group with the higher ratio of concentrate. This could be explained that since BAFLOP contained a high level of minerals it could regulate the ruminal $\mathrm{pH}$ which led to increasing in microbe activity. It is well established that microbial degradation of fiber is inhibited at $\mathrm{pH} 6.0$ and below (Terry et al., 1969). Moreover, it was reported that addition of $\mathrm{NaHCO}_{3}$ reduced the depression in ruminal $\mathrm{pH}$, thereby improving nutrient digestibility (Terry et al., 1969). Emmanuel et al. (1970) and Osbourn et al. (1970) explained that inhibition of cellulolysis due to depression in ruminal $\mathrm{pH}$ on high concentrate diets could be avoided by using bicarbonate.

Results in the present study agreed with the finding of Mould et al. (1983), who reported that the rumen $\mathrm{pH}$ has to be maintained above 6.0 in order to maintain rumen fibrolytic activities when forages are supplemented with rapidly fermentable carbohydrate, because fibrolytic in the rumen is pH dependent (Terry et al., 1969; Stewart, 1977). Based on the report of Santra et al. (2003), apparent digestibility of $\mathrm{OM}, \mathrm{CP}$ and gross energy were similar in the groups supplemented or unsupplemented with buffer 
minerals, while cellulose digestibility was higher in lambs supplemented with sodium bicarbonate. This was in accordance with the present finding which showed higher digestibility of true and NDF with BAFLOP supplementation. Furthermore, supplementation of minerals in the diet of animals is known to increase the number of total ruminal bacteria especially the cellulolytic bacteria which contributed to better cellulose digestibility (Koul et al., 1998). The total number of ciliate protozoa increases with dietary supplementation of sodium bicarbonate (Koul et al., 1998). Moreover, it is now well established that ruminal protozoa possess higher levels of fibrolytic activity (William and Coleman, 1992) and removal of ciliate protozoa reduces cellulose digestibility in the rumen (Santra and Karim, 2000).

\section{Effect on ruminal $\mathrm{pH}$ and fermentation}

Under this experiment, the $\mathrm{pH}$ was linearly decreased with the extension time of incubation and was found significantly lower in the treatment with a higher level of concentrate ratio. This may be due to the rapid degradation soluble carbohydrate which led to the depression of the $\mathrm{pH}$ in the high level of concentrate. The supplementation of BAFLOP exhibited no effect on $\mathrm{pH}$ in the high roughage ratio group, while it affected the high concentrate group. Supplementation of BAFLOP at 2 and $4 \%$ of total substrate could improve the $\mathrm{pH}$ as compared to the unsupplemented group. This could be due to the high content of mineral elements in BAFLOP (Table 2) which can buffer the decline of the $\mathrm{pH}$. Rumen $\mathrm{pH}$ is one of the most critical determinants for rumen function as cellulolytic bacteria fail to grow below $\mathrm{pH}$ 6.0, while a slight increase in ruminal $\mathrm{pH}$ favours the activity of these bacteria (Stewart, 1977). A high concentrate diet is known to depress rumen $\mathrm{pH}$ and led to lowering the fibre digestibility (Rogers and Davis, 1982; Snyder et al., 1983) due to alteration of the rumen microbial population. Hence, a dietary buffering agent would prevent depression in rumen $\mathrm{pH}$ associated with high concentrate feeding.

According to Santra et al. (2003) who reported that the $\mathrm{pH}$ in the rumen fluid increased linearly with the increasing level of dietary sodium bicarbonate. Sodium bicarbonate itself acts as a buffering agent to prevent sudden drops in rumen $\mathrm{pH}$. Further, in this study, addition of BAFLOP in the diet tended to increase the total number of rumen ciliate protozoa and it is now well established that rumen protozoa have a $\mathrm{pH}$ stabilizing effect in the rumen due to engulfment of excess starch from the rumen and storage as amylopectin. By ingesting starch granules, rumen protozoa decrease the rate of starch degradation in the rumen (William and Coleman, 1992) and thus, slow down the rumen fermentation process thereby preventing sudden fall in rumen $\mathrm{pH}$. Increases in ruminal $\mathrm{pH}$ with sodium bicarbonate supplementation in the diet have also been reported in lactating cows (West et al., 1986), buffaloes (Koul et al., 1998) and goats (Cetinkaya and Unal, 1992). Moreover, in both experiments from Rogers and Davis (1982) (high-grain and high roughage feeding), mineral salt infusion increased ruminal $\mathrm{pH}$ compared to water control. The increase was more dramatic when the high-grain diet was fed. This result was similar to the present finding in which BAFLOP supplementation had a greater effect on the high level of concentrate ratio group rather than high roughage.

The concentration of $\mathrm{NH}_{3}-\mathrm{N}$ was increased dramatically based on the time of incubation. However, there was no effect of BAFLOP supplementation on $\mathrm{NH}_{3}-\mathrm{N}$, while R:C did have an effect. These results may be due to a higher enzymatic breakdown of the dietary soluble fraction in high levels of concentrate. However, in the present study, there was a tendency of higher $\mathrm{NH}_{3}-\mathrm{N}$ concentration in treatments with BAFLOP supplementation. This should be the result of mineral elements contained in the BAFLOP acting as a rumen buffering agent to maintain rumen $\mathrm{pH}$. This finding was consistent with the result of Askar et al. (2011) reported an increase of $\mathrm{NH}_{3}-\mathrm{N}$ concentration when the lambs were supplemented with dietary mineral sodium bicarbonate as compared to unsupplemented. This was due to the enhancement of $\mathrm{pH}$ which led to the increase in dry matter digestibility, especially cellulose. Moreover, Wiedmeier et al. (1987) also reported similar finding that $\mathrm{NH}_{3}-\mathrm{N}$ tended to be increased by dietary $\mathrm{NaHCO}_{3}$ and $\mathrm{NaCl}$. The trend towards increased ruminal $\mathrm{NH}_{3}-\mathrm{N}$ could be associated with increased protein solubility measured as ruminal pH increases (Kilmer et al., 1981).

The C2 and C3 were significantly affected by the BAFLOP supplementation, while C4 and TVFA were stable at all incubation times. The $\mathrm{C} 2$ was linearly increased by the BAFLOP supplementation, while C3 was reduced. However, this effect was found only in the group with higher level of concentrate ratio. The ratio $\mathrm{C} 2$ to $\mathrm{C} 3$ and $\mathrm{CH} 4$ were found lower in the group with higher level of concentrate ratio. The increase of $\mathrm{C} 2$ and reduction of $\mathrm{C} 3$ in the group with BAFLOP supplementation could be the result of the $\mathrm{pH}$ enhancement from mineral elements in BAFLOP stimulating bacterial fiber digestion. According to West et al. (1986), rumen VFA were not different among treatments, but cattle supplemented with $\mathrm{K}_{2} \mathrm{CO}_{3}$ and $\mathrm{NaHCO}_{3}$ had a tendency toward greater total VFA and $\mathrm{C} 2: \mathrm{C} 3$ ratios. Others have reported increased in $\mathrm{C} 2$ and C2:C3 ratios using $\mathrm{NaHCO}_{3}$ (Rogers and Davis, 1982). Although $\mathrm{K}_{2} \mathrm{CO}_{3}$ was in lower concentration than $\mathrm{NaHCO}_{3}$, it elicited equal or greater responses than the other treatments. Rogers and Davis (1982) reported that intraruminal infusions of mineral salts reduced production rates of $\mathrm{C} 3$ when the high-grain diet was fed which is 
similar to the present finding. Intraruminal infusions of mineral salts in steers fed the high-roughage diet were without effect on the production rate of VFA. Alteration of the ratio of $\mathrm{C} 2 / \mathrm{C} 3$ with mineral salts is a result of a decrease in production of $\mathrm{C} 3$ in the rumen because the production rate of $\mathrm{C} 2$ was not affected. This finding was in agreement with the present finding which showed the reduction of $\mathrm{C} 3$ by the BAFLOP supplementation. Production of VFA is not the effective net production rates. Extensive interconversion between $\mathrm{C} 2$ and $\mathrm{C} 4$ occurs which leads to an overestimation of actual amounts of VFA produced in the rumen (Leng and Brett, 1966; Esdale et al., 1986). Interconversion of carbon between $\mathrm{C} 3$ and $\mathrm{C} 2$ or $\mathrm{C} 4$, however, is generally low and, thus, would not bias appreciably the estimate for propionate production.

\section{Effect on rumen microbes}

The results revealed the significant effect on bacterial populations by different $\mathrm{R}: \mathrm{C}$ and the BAFLOP supplementation while protozoal and fungi zoospores showed a tendency effect by the BAFLOP supplementation. As compared with the unsupplemented group, the supplementation was found higher in bacteria, fungi and protozoa populations. This effect may be due to BAFLOP containing a high level of minerals. As been reported, branched chain VFAs is stimulatory to ruminal cellulolytic bacteria (Bryant, 1973). The combination of increased ruminal $\mathrm{pH}$ (Wiedmeier et al., 1987) and branched chain VFA pools measured with dietary $\mathrm{NaHCO}_{3}$ and $\mathrm{NaCl}$ would account for the increased percent cellulolytic bacteria measured. A trend towards increased bacterial cell production was measured with $\mathrm{NaHCO}_{3}$ and $\mathrm{NaC} 1$ treatments. This agreed with the present finding that BAFLOP contains high mineral elements which could buffer the rumen ecology.

According to Santra et al. (2003), the highest numbers of total ciliate protozoa, Isotricha, Dasytricha and large and small spirotrichs were observed in mineral supplementation groups. The increase in the number of ciliate protozoa with mineral supplementation in the diet was also observed by Garg and Nagia (1991) and Koul et al. (1998) in buffaloes. Generally, slightly alkaline ruminal $\mathrm{pH}$ favours ruminal protozoal growth while their growth is disturbed when the $\mathrm{pH}$ falls below 6.0 and the rumen protozoa are completely eliminated at $\mathrm{pH} 5.5$ and below. Hence, higher ciliate protozoal counts in sodium bicarbonate supplemented groups were possibly due to their higher ruminal $\mathrm{pH}$. The lowest total ciliate protozoal count was observed just before feeding in all the experimental groups, followed by an abrupt increase in the number of holotrich as well as spirotrich protozoa at $3 \mathrm{~h}$ post-feeding in supplemented grounds whereas the protozoal number gradually increased up to $6 \mathrm{~h}$ post-feeding in the lambs of unsupplemented group. Furthermore, in this study, addition of $\mathrm{NaHCO}_{3}$ in the diet increased the total number of rumen ciliate protozoa and it is now well established that rumen protozoa have a $\mathrm{pH}$ stabilizing effect in the rumen due to engulfment of excess starch from the rumen and storage as amylopectin. By ingesting starch granules, rumen protozoa can decrease the rate of starch degradation in the rumen (William and Coleman, 1992) and thus, slow down the rumen fermentation process thereby preventing sudden fall in rumen $\mathrm{pH}$.

Predominant cellulolytic bacteria in in vitro incubation were affected by the R:C ratio, except for $R$. flavefacience which was similar to the finding of Anantasook and Wanapat (2012). Due to BAFLOP acting as a rumen buffering agent there was an increased ruminal bacterial growth. Wanapat and Cherdthong (2009), Koike and Kobayashi (2001) and Russell and Rychlik (2001) reported that the level of concentrate in the diet could influence the population size or the proportion of cellulolytic bacteria numbers in the rumen. In addition, the three cellulolytic bacteria species examined in the present study were different in their response to low and high concentrate proportions. As the results showed, the population of $F$. succinogenes and $R$. albus were the lowest in R:C of 25:75 without BAFLOP supplementation, while $R$. flavefaciens numbers quadratically increased with an increasing level of concentrate in the diet. It is possible that dietary conditions reduced the numbers of cellulolytic bacteria. Furthermore, the type of feed, environmental factors such as temperature, $\mathrm{pH}$ and the existence of cations and soluble carbohydrate have been suggested as factors governing bacterial attachment (Miron et al., 2001). In the present study, the quantification of bacteria DNA demonstrated a decrease in the numbers of the three cellulolytic bacteria ( $F$. succinogenes, $R$. flavefaciens, and $R$. albus) with higher levels of concentrate, but their numbers were enhanced by BAFLOP supplementation.

\section{CONCLUSIONS AND RECOMMENDATIONS}

Based on this finding, it could be concluded that the rumen ecology was affected by the ratio of roughage to concentrate. The $\mathrm{pH}$ significantly declined with a high level of concentrate. The supplementation of banana flower powder can buffer rumen $\mathrm{pH}$ which leads to an improvement of the rumen efficiency performance such as digestibility, fermentation end products and microorganism growth. This study suggested that the supplementation of BAFLOP could be used as the mineral source for rumen buffering and thus, enhancing rumen ecology with high concentrate diets both in buffalo and cattle. The level of BAFLOP supplementation could be used at 2 to $4 \%$ of total dry matter substrate. Further research using BAFLOP as a 
rumen buffering agent in in vivo feeding trials is urgently required.

\section{ACKNOWLEDGEMENTS}

Thanks are due to the Tropical Feed Resources Research and Development Center (TROFREC) and Khon Kaen University for the granting the scholarship for the first author's Ph.D study and the research funding and facilities; Department of Animal Science, Faculty of Agriculture, Khon Kaen University, Thailand for providing experimental animals and research facilities for the present work. The authors also wish to acknowledge Agricultural Biotechnology Research Center, Khon Kaen University for real-time PCR analysis and for technical support.

\section{REFERENCES}

Anantasook, N. and M. Wanapat. 2012. Influence of rain tree pod meal supplementation on rice straw based diets using in vitro gas fermentation technique. Asian-Aust. J. Anim. Sci. 25:325334.

AOAC. 1990. Official methods of analyses, 15th edn. Assoc. Offic. Anal. Chem, Arlington, VA.

Askar, A. R., J. A. Guada, J. M. Gonzalez, A. de Vega, and C. Castrillo. 2011. Effect of sodium bicarbonate on diet selection and rumen digestion by growing lambs individually fed whole barley grain and a protein supplement at their choice. Anim. Feed Sci. Technol. 164:45-52.

Barry, T. N. and T. R. Manley. 1984. The role of condensed tannins in the nutritional value of Lotus pedunculatus for sheep: Quantitative digestion of carbohydrates and proteins. Br. J. Nutr. 51:493-504.

Barry, T. N., T. R. Manley, and S. J. Duncan. 1986. The role of condensed tannins in the nutritional value of Lotus peduculatus for sheep (sites of carbohydrate and protein digestion as influenced by dietary reactive tannin concentration). Br. J. Nutr. 55:123-137.

Blummel, M. and E. R. Orskov. 1993. Comparison of in vitro gas production and nylon bay degradability of roughages in prediction feed intake in cattle. Anim. Feed Sci. Technol. 40: 109-119.

Bryant, M. P. 1973. Nutritional requirements of the predominant rumen cellulolytic bacteria. Fed. Proc. 32:1809-1813.

Cetinkaya, N. and S. Unal. 1992. Effects of bicarbonate on rumen degradability of concentrate and grass hay in Angora goats. Small Rumin. Res. 9:117-123.

Chanthakhoun, V. and M. Wanapat. 2012. The in vitro gas production and ruminal fermentation of various feeding using rumen liquor from swamp buffalo and cattle. Asian J. Anim. Vet. Adv. 7:54-60.

Crichton, N. 1999. Information point: Tukey Multiple Comparison test. Blackwell Science Ltd, J. Clinical Nursing, 8:299-304.

Emmanuel, B., M. J. Lawlor, and D. McAleese. 1970. The effect of phosphate and carbonate-bicarbonate supplements on the rumen buffering system of sheep. Br. J. Nutr. 24:653-660.

Esdale, W. J., G. A. Brodetick, and L. D. Sarter. 1968.
Measurement of ruminal volatile fatty acid production from alfalfa hay or corn silage rations using a continuous infusion isotope dilution technique. J. Dairy Sci. 51:1823-1823.

Franzolin, R. and B. A. Dehority. 1996. Effect of prolonged concentrate feeding on ruminal protozoa concentration. J. Anim. Sci. 74:2803-2809.

Galyen, M. 1989. Laboratory procedures in animal nutrition research. New Mexico State University.

Garg, S. L. and O. P. Nagia. 1991. Studies on dilution rate and pattern of rumen fermentation by inclusion of sodium bicarbonate in the diet of buffaloes. Int. J. Anim. Sci. 6:111121

Hussain, A. and E. L. Miller. 1999. Effect of sucrose and lactose with sodium bicarbonate on rumen metabolism and microbial protein synthesis in sheep (abstract). J. Annul. Proc. Anim. Sci. $77: 28$.

Khazaal, K., M. T. Dentinho, J. M. Riberrio, and E. R. Orskov. 1993. A comparison of gas production during incubation with rumen contents in vitro and nylon bag degradability as predictors of the apparent digestibility in vivo and voluntary intake of hays. Anim. Prod. 57:105-112.

Kilmer, L. H., L. D. Muller, and T. J. Snyder. 1981. Addition of sodium bicarbonate to rations of postpartum dairy cows: physiological and metabolic effects. J. Dairy Sci. 64:23572369.

Koike, S. and Y. Kobayashi. 2001. Develop and use of competitive PCR assays for the rumen cellulolytic bacteria: Fibrobactor succinogenes, Ruminococcus albus and Ruminococcus flavefaciens. FEMS Microbiol. Lett. 204:361-366.

Koul, V., U. Kumar, V. K. Sareen, and S. Singh. 1998. Effect of sodium bicarbonate supplementation on ruminal microbial populations and metabolism in buffalo calves. Ind. J. Anim. Sci. 68:629-631.

Lane, D. J. 1991. 16S/23S rRNA sequencing. In: Nucleic Acid Techniques in Bacterial Systematics (Ed. E. Stackebrandt and M. D. Goodfellow). John Wiley, and Sons. New York, NY, USA. pp. 115-175.

Leng, R. A. and D. J. Bretr. 1966. Simultaneous measurements of the rates of production of acetic, propionic and butyric acids in the rumen of sheep on different diets and the correlation between production rates and concentrations of these acids in the rumen. Br. J. Nutr. 20:541-552.

Lusin, R. and M. Wanapat. 2010. Effect of roughage to concentrate ratio and rice bran oil supplementation on rumen fermentation characteristics using in vitro gas production technique. Proc. 14th AAAP conference at pingtung university, Taiwan, pp. 353-356.

Makkar, H. P. S., M. Blummel, and K. Becker. 1995. Formation of complexes between polyvinyl pyrrolidones or polyethylene glycols and tannins, and their implication in gas production and true digestibility in in vitro techniques. Br. J. Nutr. 73: 897-913.

Mandebvu, P. and H. Galbraith. 1999. Effect of sodium bicarbonate supplementation and variation in the proportion of barley and sugar beet pulp on growth performance and rumen, blood and carcass characteristics in young entire lambs. Anim. Feed Sci. Technol. 82:37-49.

McDonald, P., R. A. Edward, J. F. Greenhalgh, and C. A. Morgan. 1996. Animal Nutrition. Logman Scientific and Technical, 
Harlow, UK.

Menke, K. H. and H. Steingass. 1988. Estimation of the energetic feed value obtained from chemical analysis and gas production using rumen fluid. Anim. Res. Dev. 28:7-55.

Menke, K. H., L. Raab, A. Salewski, H. Steingass, D. Fritz, and W. Schneider. 1979. The estimation of the digestibility and metabolizable energy content of ruminant feedstuffs from the gas production when they are incubated with rumen liquor in vitro. J. Agric. Sci. (Camb.) 92:217-222.

Miron, J., D. Ben-Ghedalia, and M. Morrison. 2001. Invited review: Adhesion mechanisms of rumen cellulolytic bacteria. J. Dairy Sci. 84:1294-1309.

Moss, A. R., J. P. Jouany, and J. Newbold. 2000. Methane production by ruminants: its contribution to global warming. Ann. Zootech. 49:231-253.

Mould, F. L., E. R. Ørskov, and S. A. Gauld. 1983. Associative effect of mixed feeds. II. Effect of dietary addition of bicarbonate salts on the voluntary intake and digestibility of diets containing various proportions of hay and barley. Anim. Feed Sci. Technol. 10:31-47.

Ngamsaeng, A., M. Wanapat, and S. Khampa. 2006. Evaluation of local tropical plants by in vitro rumen fermentation and their effects on fermentation end-products. Pak. J. Nutr. 5:414-418.

Orskov, E. R. and I. McDonal. 1979. The estimation of protein degradability in the rumen from incubation measurements weighted according to rate of passage. J. Agric. Sci. 92:499503.

Osbourn, D. F., R. A. Terry, S. B. Cammell, and G. E. Outen. 1970. Some effects of feeding supplements of maize meal and sodium bicarbonate upon the digestion of forage cellulose by sheep. Proc. Nutr. Soc. 29:12-13.

Owens, F. N., D. S. Secrist, W. J. Hill, and D. R. Gill. 1998. Acidosis in cattle: a review. J. Anim. Sci. 76: 275-286.

Reed, J. D., H. Soller, and A. Woodward. 1990. Fodder tree and straw diets for sheep: Intake, growth, digestibility and the effects of phenolics on nitrogen utilisation. Anim. Feed Sci. Technol. 30:39-50.

Rogers, J. A. and C. L. Davis. 1982. Effects of intraruminal infusions of mineral salts on volatile fatty acid production in steers fed high-grain and high-roughage diets. J. Dairy Sci. 65: 953-962.

Russell, J. B. and J. L. Rychlik. 2001. Factors that alter rumen microbial ecology. Science 292:1119-1122.

Samuel, M., S. Sagathewan, J. Thomus, and G. Mathen. 1997. An HPLC method for estimation of volatile fatty acids of rumenfluid. Indian J.Anim. Sci. 67:805-807.

Santra, A. and S. A. Karim. 2000. Growth performance of faunated and defaunated Malpura weaner lambs. Anim. Feed Sci. Technol. 86:251-260.
Santra, A., O. H. Chaturvedi, M. K. Tripathi, R. Kumar, and S. A. Karim. 2003. Effect of dietary sodium bicarbonate supplementation on fermentation characteristics and ciliate protozoal population in rumen of lambs. Small Rumin. Res. 47:203-212.

SAS. 1998. User's Guide: Statistic, Version 6, 12th Edition. SAS Inst. Inc., Cary, NC.

Slyter, L. L. 1976. Influence of acidosis on rumen function. J. Anim. Sci. 43:910-929.

Snyder, T. J., J. A., Rogers, and L. D. Muller. 1983. Effect of 1.2\% sodium bicarbonate with two ratios of cornsilage:grain on milk production, rumen fermentation and nutrient digestion by lactating dairy cows. J. Dairy Sci. 66:1290-1297.

Stewart, C. S. 1977. Factors affecting the cellulolytic activity of rumen contents. Appl. Environ. Microbiol. 33:497-502.

Sylvester, J. T., S. K. R. Karnati, Y. Zhongtang, M. Morrison, and J. L. Firkins. 2004. Development of an assay to quantify rumen ciliate protozoal biomass in cows using real-time PCR. J. Nutr. 134:3378-3384.

Tanner, A., M. F. Maiden, B. J. Paster, and F. E. Dewhirst. 1994. The impact of $16 \mathrm{~S}$ ribosomal RNA-based phylogeny on the taxonomy of oral bacteria. Periodontol. 2000. 5:26-51.

Terry, R. A., J. M. A. Tilly, and G. E. Outen. 1969. Effect of pH on cellulose digestion under in vitro condition. J. Sci. Food Agric. 20:317-320.

Tripathi, M. K., A. Santra, O. H. Chaturvedi, and S. A. Karim. 2004. Effect of sodium bicarbonate supplementation on ruminal fluid $\mathrm{pH}$, feed intake, nutrient utilization and growth of lambs fed high concentrate diets. Anim. Feed Sci. Technol. 111:27-39.

Van Soest, P. and J. B. Robertson. 1985. A laboratory manual for animal science. Cornell University Press, Ithaca, NY, page. 612

Wanapat, M. and A. Cherdthong. 2009. Use of real-time PCR technique in studying rumen cellulolytic bacteria population as affected by level of roughage in Swamp buffalo. Curr. Microbiol. 58:294-299.

West, J. W., C. E. Coppock, D. H. Nave, and G. T. Schelling. 1986. Effects of potassium buffers on feed intake in lactating dairy cows and on rumen fermentation in vivo and in vitro. J. Dairy Sci. 69:124-134.

Wiedmeier, R. D., M. J. Arambel, R. C. Lamb, and D. P. Marcinkowski. 1987. Effect of mineral salts, carbachol, and pilocarpine on nutrient digestibility and ruminal characteristics in cattle. J. Dairy Sci. 70:592-600.

William, A. G. and G. S. Coleman. 1992. The Rumen protozoa. Springer, New York.

Yu, Z. and M. Morrison. 2004. Improved extraction of PCRquality community DNA from digesta and fecal samples. Biotechniques 36:808-812. 